\title{
HUBUNGAN ANTARA SIKAP TERHADAP KERJASAMA KELOMPOK DENGAN KEPUASAN KERJA PADA KARYAWAN
}

\author{
KM. Amran Nurzaman \\ Fakultas Psikologi UIN Sunan Gunung Djati Bandung, Jl. A.H Nasution No. 105 Bandung \\ email: am_radja@yahoo.com
}

\begin{abstract}
Abstrak
Penelitian yang dilakukan pada karyawan PT Pindad Persero ini berawal dari ketertarikan peneliti untuk melihat bagaimana dinamika hubungan dalam kelompok yang terjadi, sebab jenis pekerjaaan yang ada dalam perusahaaan sifatnya harus dikerjakan secara berkelompok. Bilamana salah seorang pekerja kurang mampu kooperatif dalam menyelesaikan tugas, maka hasil yang dicapai akan kurang maksimal dan hubungan antar rekan sejawat menjadi kurang harmonis sebab satu sama lain merasa ada pembebanan tugas pada anggota lain. Metoda penelitian yang digunakan adalah metoda penelitian kuantitatif dengan analisis korelasi. Pengambilan sampel dilakukan dengan menggunakan teknik purposive technic sampling. Alat ukur yang digunakan adalah skala sikap dan skala kepuasan kerja NSQ (Need Statisfaction Questionere) dari Porter (1961). Alat ukur tersebut dirancang dengan menggunakan skala Likert yang menghasilkan data dengan tingkatan pengukuran ordinal. Hasil analisis data memperlihatkan koefisien korelasi sebesar $r_{s}=-0,125$. setelah dilakukan uji signifikasi dengan statistik uji t diperoleh $t_{\text {hitung }}$ sebesar $-0,88$ sesuai dengan kriteria uji diperoleh simpulan bahwa dalam penelitian ini terdapat korelasi namun kurang signifikan, yakni sekitar 0,156\%. Berdasarkan pengolahan data, dapat disimpulkan bahwa semakin tinggi sikap terhadap kerjasama kelompok maka semakin tinggi pula tingkat kepuasan kerja.
\end{abstract}

Kata kunci : sikap, kerjasama kelompok, dan kepuasan kerja

\section{Abstract}

This research has observed workers in PT Pindad Persero and it purposes to know how correlation dynamic in groups, because the kind of works in this PT Pindad Persero is works that must be done in group. If one of workers cannot cooperate in doing work, the achieved result will not maximum and the relation between partners will not be harmony because there is an assignment load. The research method used is quantitative research with correlative analysis. Taking sample is done by using purposive technique sampling. The measurement tool used is attitude scale and Need Satisfaction Questioner (NSQ) from Porter (1961). The measurement tool is designed by using Likert scale producing the data with ordinal measurement level. The result of data analysis shows $r_{s}=-0,125$. After doing significance test with test statistic, it is known that $t=-0,88$, it appropriates with test criteria. In conclusion, there is a correlation in this research but it not so significant, i.e., about 0,156 percent. Basing on processing the data, it concludes that getting higher the attitude of group cooperation is, getting higher the work satisfactory level will be.

Key words: attitude, group cooperation, and work satisfaction 


\section{PENDAHULUAN}

Belakangan ini semakin pesat akan perkembangan organisasi yang ada di Indonesia, tentunya memberikan konsekuensi meningkatnya tuntutan pekerjaan dan pekerja atau individu yang ada dalam organisasi dituntut untuk lebih mampu menyesuaikan diri dengan perubahan-perubahan yang terjadi.

Pengembangan kemampuan kerja individu dimaksudkan untuk membentuk atau menggali seluruh kemampuan yang dimiliki oleh individu, sehingga diharapkan individu mampu menjawab tantangan jaman. Individu dituntut untuk senantiasa menyesuaikan diri, mampu bergerak dengan cepat, dituntut untuk lebih mampu mencari alternatif dalam mencari pemecahan masalah yang dihadapi serta bisa untuk diajak bekerjasama.

Potensi dan kemampuan tenaga kerja perlu dikembangkan terus menerus, sehingga daya guna dapat semakin meningkat dan individu tidak saja dilihat sebagai mahluk yang berkebutuhan sandang-pangan-papan, keamanan, sosial, dan penghargaan, tetapi juga sebagai mahkluk yang berkebutuhan untuk mengaktualisasikan dirinya (Munandar, 1988).

Untuk mencapai tujuan organisasi perlu mengadakan pembagian kerja, sebagai upaya dalam mengefektifkan dan mengefesiensikan sumber daya manusia dan dalam usahanya pembentukan kelompok-kelompok kerja merupakan salah satu alternatif yang bisa dilakukan untuk melakukan pembagian tugas dan peran yang harus dilaksanakan oleh individuindividu sebagai anggota kelompok.

Kemampuan dalam melakukan hubungan interpersonal oleh anggota kelompok sangat berpengaruh pada kedinamisan di dalam kelompok, jika anggota kelompok mampu saling memahami maka tujuan dari adanya pembagian kelompok dalam kerja mungkin dapat tercapai. Kelompok adalah merupakan bagian dari organisasi, pemanfaatan sumber daya manusia dalam kelompok berpengaruh pada pengembangan organisasi secara menyeluruh. Menurut Wexley \& Yuki (1977: 159) kelompok adalah "himpunan orang yang saling berinteraksi secara teratur dalam periode tertentu dan menyadari ketergantungan sesama anggota untuk mencapai satu atau beberapa tujuan".

Sikap positif merupakan faktor pendorong utama bagi karyawan untuk bekerja se- maksimal mungkin, dalam hal kerjasama sikap positif dari tiap anggota kelompok sangat berpengaruh pada performance kelompok. Sebaliknya dengan sikap negatif yang ditunjukkan oleh anggota kelompok dapat menimbulkan prilaku yang merugikan bagi kelompok dan performance kelompok menjadi buruk.

Sikap positif dari anggota dalam kerjasama kelompok muncul karena adanya kondisi yang dirasakan dapat memenuhi kebutuhannya, memandang penting, merasa setuju/suka, merasa senang/nyaman terhadap pekerjaannya, sedangkan bila kondisi yang dirasakan adalah menghambat kebutuhannya, memandang tidak penting, merasa tidak setuju/tidak suka, dan merasa tidak senang/kurang nyaman maka akan menimbulkan sikap negatif dan membuat individu/pekerja menjadi tidak puas.

Sikap adalah gejala internal yang berdimensi afektif berupa kecenderungan untuk mereaksi atau merespon (response tendency) dengan cara yang relatif tetap terhadap objek orang, barang dan sebagainya, baik secara positif maupun negatif, (Muhibbin 2005: 135).

Dengan sikap positif yang ditunjukkan oleh anggota kelompok terhadap pekerjaan yang dihadapi akan membuat atau menciptakan suasana keakraban dan saling mendukung antar rekan sejawat sehingga menimbulkan kepuasan kerja, sebaliknya jikia sikap negatif yang ditunjukkan oleh anggota kelompok maka memungkin anggota kelompok yang lain menjadi tidak senang dan hal ini akan menimbulkan ketidakpuasan. Kepuasan kerja menurut Howell dan Dipboye (dalam Munandar, 2001 : 350) kepuasan kerja sebagai hasil keseluruhan dari derajat rasa suka atau tidak sukanya tenaga kerja terhadap berbagai aspek dari pekerjaannya. Dengan kata lain kepuasan kerja mencerminkan sikap tenaga kerja terhadap pekerjaannya.

Pada perusahaan PT Pindad persero (pada divisi tempa \& cor) Bandung, berdasarkan hasil wawancara dengan beberapa orang karyawan dan salah satu Kabag Personalia bahwa pada divisi ini pekerjaan yang harus diselesaikan sifatya harus dilakukan dengan cara kerja kelompok. Dan menurutnya kemampuan untuk bisa bekerjasama sangat menunjang dalam mecapai hasil yang optimal, namun demikian bukan hal yang mudah untuk mewujudkan kekompakan dalam kerja kelompok. 
Karakteristik dari pekerjaan tempa dan cor termasuk pekerjaan kasar, artinya bahwa pekerjaan ini memerlukan tenaga yang ekstra. Misalnya pada saat akan melakukan pengecoran, maka harus dikerjakan secara bersamasama. Atau ketika melakukan penempaan pada baja agar sesuai dengan pola yang telah dibuat maka hal ini harus dilakukan bersama-sama, sebab ada yang mendapat bagian pengapian, mengangkat baja dan menempa.

Dari wawancara peneliti dengan Staf Personalia pada studi pendahuluan, bahwa kerjasama dalam kelompok sangat penting dalam menjalankan tugas. Maksud kerjasama dalam kelompok disini ialah setiap pekerja dalam departemen yang sama dituntut untuk mampu menyesuaikan diri agar dapat bekerjasama dengan siapa saja di dalam kelompoknya sebab pekerjaan yang dilakukan harus berkelompok.

Akan tetapi terkadang para pekerja sulit untuk diajak bekerjasama dan lebih bersikap menunjukkan kemampuan pribadinya, seperti kurang melibatkan anggota yang lain dalam menyelesaikan tugas, yang akhirnya justru akan merugikan perusahaan. Menurutnya sikap seperti ini akan menimbulkan suasana kurang harmonis dalam kelompok, dan pekerja yang lainnya menjadi kurang bersemangat dalam bekerja dan membuat para pekerja ada yang suka mengeluh merasa kurang puas karena merasa tidak dihargai.

Dari sikap negatif yang ditunjukkan membuat hubungan interpersonal antar anggota kelompok menjadi kurang harmonis yang akhirnya terkadang pekerja menjadi malas dan tidak bersemangat untuk bekerja sehingga akhirnya hasil produksi akan menjadi kurang optimal, bilamana hal ini terus berlarut maka tentu akan sangat merugikan bagi perusahaan.

Oleh karena itu untuk mengatasi hal tersebut perusahaan mencoba melakukan program rotasi pada pekerja yang baru dimulai, program ini dilakukan enam tahun sekali, dengan maksud agar pekerja mampu menyesuaikan diri dalam berbagai suasana lingkungan dan bisa bersikap lebih positif terhadap jenis pekerjaan yang sifatnya menuntut untuk dilakukan bersama, selain itu juga antara lain supaya pekerja tidak merasa jenuh dan mendapatkan suasana baru sehingga diharapkan mutu kerja bisa lebih ditingkatkan lagi.

Berdasarkan keterangan yang didapat dari salah seorang Staf Administrasi dan keuangan (ibu Z), bahwa terkadang ada beberapa orang pekerja (30\%) yang mengeluh merasa tidak puas. Menurutnya hal ini terjadi salah satunya karena adanya sikap kurang baik yang ditunjukkan oleh anggota kelompok dan lebih memberikan pembebanan tugas pada anggota kelompok yang lain sedangkan tugas yang harus dikerjakan adalah sifatnya bersama-sama, disni ada sikap yang kurang baik dalam hubungan rekan kerja.

Seperti yang terjadi pada departemen tempa, ia sering mendapatkan laporan-laporan dari rekan-rekan stafnya. Dari hasil wawancara peneliti dengan Staf tersebut bahwa pekerja merasa tidak puas bilamana dalam kelompoknya ada yang bersikap kurang baik dengan tidak ikut bekerja, sehingga membuat anggota lain menjadi kurang puas, salah satu sikap yang dimunculkan adalah pekerja menjadi malas bekerja karena merasa tidak adanya dukungan dari rekan-rekannya untuk sama-sama menyelesaikan tugas yang diberikan.

Dari fenomena di atas menimbulkan suatu permasalahan yang menarik bagi penulis untuk menelitinya, sebab disatu sisi kerjasama kelompok akan menghasilkan produktivitas yang optimal dan menciptakan suasana harmonis antar anggota kelompok. Namun disatu sisi kerjasama kelompok akan dapat menghambat organisasi karena kurang harmonisnya individu anggota kelompok, karena sikap kurang baik yang ditunjukkan oleh anggotanya yakni dengan tidak bisa saling mengisi kekurangan yang ada pada kelompok.

Masalah ini menimbulkan keinginan bagi peneliti untuk mendapatkan kejelasan lebih lanjut mengenai hubungan antara sikap terhadap kerjasama kelompok dengan kepuasan kerja pada karyawan PT. Pindad Persero (departemen tempa \& cor) Bandung.

\section{Sikap}

Beberapa ahli memberikan batasan-batasan mengenai pengertian sikap yang berbedabeda menurut konsep teorinya, namun demikian ada benang merah yang dapat diambil sebuah simpulan mengenai batasan-batasan tentang sikap. Berikut adalah beberapa pendapat tentang pengertian sikap menurut beberapa tokoh, yaitu:

Menurut Thurstone (1928. Azwar, 2003: 5), sikap adalah sebagai derajat afek positif atau afek negatif terhadap suatu objek Psikologis. 
La Pierre (1934. dalam Azwar, 2003: 5) menyebutkan bahwa sikap adalah sebagai suatu pola prilaku, tendensi atau kesiapan antisipatif, predisposisi untuk menyesuaikan diri dalam situasi sosial atau secara sederhana, sikap adalah respons terhadap stimuli sosial yang telah terkondisikan.

Menurut Gerungan (2002: 149), sikap adalah merupakan attitude/sikap dan kesediaan bereaksi terhadap sesuatu hal dan senantiasa selalu ter-arahkan terhadap suatu hal, suatu objek atau lainnya, tidak ada attitude tanpa adanya objek

Menurut Allport, (O. Sear, 1994: 137) sikap adalah keadaan mental dan saraf dari kesiapan yang diatur melalui pengalaman yang memberikan pengaruh dinamik atau terarah terhadap respons individu pada semua objek dan situasi yang berkaitan dengannya.

Menurut Syah (2005: 135) Sikap merupakan gejala internal yang berdimensi afektif berupa kecenderungan untuk mereaksi atau merespon (response tendency) dengan cara yang relatif tetap terhadap objek orang, barang dan sebagainya, baik secara positif maupun negatif.

Menurut Robbins (2001: 138) sikap adalah pernyataan evaluatif baik yang menguntungkan atau tidak menguntungkan mengenai obyek, orang, atau peristiwa.

Azwar (2003: 4 - 5), menggolongkan definisi sikap kedalam tiga kerangka pemikiran dari para tokoh psikologi, yaitu: Golongan pertama, kerangka pemikiran yang diwakili oleh para ahli psikologi seperti Osgood. dkk. Menurut mereka sikap adalah suatu bentuk evaluasi atau reaksi perasaan. Berarti sikap seseorang terhadap suatu objek adalah perasaan mendukung atau memihak (favorable) maupun perasaan tidak mendukung atau tidak memihak (unfavorable) pada objek tersebut.

Golongan kedua, kerangka pemikiran ini diwakili oleh ahli seperti Allport. dkk. Menurut kelompok pemikiran ini sikap merupakan semacam kesiapan untuk bereaksi terhadap suatu objek dengan cara-cara tertentu. Dapat dikatakan bahwa kesiapan yang dimaksudkan merupakan kecenderungan yang potensial untuk bereaksi dengan cara tertentu apabila individu dihadapkan pada suatu stimulus yang menghendaki adanya respon.

Golongan ketiga, kelompok pemikiran ini adalah kelompok yang berorientasi pada skema triadik (triadic schema). Menurut pe- mikiran ini suatu sikap merupakan konstelasi komponen kognitif, afektif dan konatif yang saling berinteraksi didalam memahami, merasakan dan berperilaku terhadap suatu objek.

Berdasarkan batasan-batasan tersebut maka bisa dikatakan, sikap merupakan predisposisi yang ada pada diri individu untuk bereaksi terhadap lingkungannya baik secara positif maupun negatif yang melibatkan aspek afektif, kognitif dan konasi.

Tingkah laku manusia merupakan reaksi terhadap rangsang-rangsang yang berasal dari lingkungan seperti lingkungan fisik, manusia atau benda lainnya. Individu akan memberikan reaksi terhadap stimulus yang datang padanya, dengan perkataan lain bahwa individu tidak pasif dalam menerima stimulus tersebut. Persepsi sikap, nilai dan motivasi mempengaruhi kepekaan seseorang dalam menanggapi stimulus tersebut, faktor-faktor ini yang akan mempengaruhi tingkah laku (Milton, 1981: 177).

Dalam menghadapi lingkungannya seseorang akan bereaksi sesuai dengan rangsang yang diterimanya, sikap itu sendiri merupakan produk dari proses sosialisasi tersebut.

\section{Sikap}

Menurut Gerungan (2002: 154 - 157) Sikap merupakan suatu sistem yang terdiri dari tiga komponen yaitu kognisi, afeksi dan konasi. Setiap komponen berhubungan satu dengan lainnya, perubahan pada suatu komponen akan mempengaruhi komponen lain.

Kognisi, merupakan keyakinan individu tentang suatu objek, termasuk dalam hal ini adalah baik dan buruk, yang penting dan tidak penting, mengenai suatu objek. Semua pengalaman, pengertian, dan pemaknaan serta keterangan atau pengetahuan mengenai objek tertentu tercakup didalam komponen ini.

Afeksi, menyangkut unsur perasaan atau reaksi emosional terhadap suatu objek atau kejadian yang dihadapi berdasarkan pengalaman terdahulu, misalnya perasaan suka dan tidak suka terhadap suatu objek. Jika sikap diarahkan kepada objek tertentu, maka objek tersebut akan terkenai afeksinya. Pada umumnya sesuatu yang diyakini akan lebih disukai dari pada yang tidak disukai.

Konasi, kecenderungan bertindak yang diarahkan kepada suatu tujuan, individu yang mempunyai sikap positif pada suatu objek maka tingkah lakunya akan diarahkan kepada 
objek tersebut dan cenderung akan mendekatinya. Sebaliknya jika sikapnya terhadap suatu objek negatif dan ada perasaan tidak menyenangkan, maka sikapnya akan menghindarinya.

Komponen sikap mempunyai fungsi masing-masing akan tetapi komponen-komponen tersebut membentuk suatu kesatuan yang terintegrasi. Artinya apabila suatu komponen tidak berfungsi maka terjadi ketidakseimbangan.

Sikap memilki evaluasi positif dan negatif yang bersifat emosional yang disebabkan oleh komponen afektif, pengetahuan dan perasaan tadi menghasilkan tingkah laku tertentu. Objek yang pertama dihadapi pertama-tama berhubungan dengan pemikiran, penalaran seseorang, sehingga komponen kognisi melukiskan objek tersebut. Komponen konasi merupakan kecenderungan bertingkah laku, yaitu bentuk kesediaan bertingkah laku sesuai dengan sikapnya. Bila individu memilki sikap positif terhadap suatu objek, maka ia akan memberi reaksi menerima atau mendukung objek tersebut. Jika sikapnya negatif terhadap objek, maka ia akan cenderung menghindarinya.

Manusia tidak dilahirkan dengan sikap pandangan ataupun sikap perasaan tertentu, tetapi attitude tersebut dibentuk sepanjang perkembangannya. Peranan attitude dalam kehidupan manusia sangat besar, sebab apabila sudah dibentuk pada diri manuasia maka attitude-atttiude itu akan turut menentukan cara-cara tingkah lakunya terhadap objek-objek attitudenya. Adanya attitude-attitude menyebabkan bahwa manusia akan bertindak secara khas terhadap objek-objeknya.

Menurut Azwar (2003: 30 - 38) ada beberapa faktor yang mempengaruhi pembentukan sikap dalam interaksi sosialnya, yakni:

Pengalaman pribadi. Apa yang telah dan sedang kita alami akan ikut membentuk dan mempengaruhi penghayatan kita terhadap stimulus sosial, apakah penghayatan itu kemudian akan membentuk sikap positif atau negatif akan tergantung pada berbagai faktor lain. Menurut Middlebrook (1974, dalam Azwar) mengatakan bahwa "tidak adanya pengalaman sama sekali dengan suatu objek psikologis cenderung akan membentuk sikap negatif terhadap objek tersebut", oleh karenanya untuk menjadi dasar pembentukan sikap maka pengalaman pribadi haruslah meninggalkan kesan yang kuat untuk mempermudah pembentukan sikap karena melibatkan faktor emosional.
Pengaruh orang lain yang dianggap penting. Orang lain disekitar kita merupakan salah satu diantara komponen sosial yang ikut mempengaruhi sikap kita, seseorang yang kita anggap penting, yang kita harapkan persetujuannya bagi setiap gerak tingkah dan pendapat kita, seseorang yang tidak ingin kita kecewakan, atau seseorang berarti khusus bagi kita (significant other), diantaranya yaitu orang tua atau teman dekat, akan banyak mempengaruhi pembentukan sikap kita terhadap sesuatu.

Pengaruh kebudayaan. Kebudayaan dimana kita hidup dan dibesarkan mempunyai pengaruh besar terhadap pembentukan sikap kita, tanpa kita sadari kebudayaan telah menanamkan garis pengaruh sikap kita terhadap berbagai masalah. Kebudayaan telah mewarnai sikap anggota masyarakat, karena ini memberi pengalaman individu-individu yang menjadi anggota kelompok masyarakat. Seorang ahli psikologi terkenal B.F Skinner (Hergenhanh, 1982) sangat menekankan pengaruh lingkungan (termasuk kebudayaan) dalam membentuk pribadi seseorang, kepribadian katanya tidak lain daripada pola prilaku yang konsisten menggambarkan sejarah reinforcement yang kita alami.

Media massa. Media masa sebagai alat komunikasi memiliki peranan dalam pembentukan sikap, dalam penyampaian informasi sebagai tugas pokoknya memberikan pesanpesan yang dapat membuat sugesti dan mengarahkan opini seseorang. Adanya informasi baru mengenai sesuatu hal memberikan landasan kognitif baru bagi terbentuknya sikap terhadap hal tersebut.

Lembaga pendidikan dan lembaga agama. Lembaga pendidikan serta lembaga agama sebagai suatu sistem mempunyai pengaruh dalam pembentukan sikap dikarenakan keduanya meletakkan dasar pengertian dan konsep moral dalam diri individu. Dikarenakan konsep moral dan ajaran agama sangat menentukan sistem kepercayaan, maka berpengaruh dalam proses pembentukkan sikap individu.

Pengaruh faktor emosional. Pembentukan sikap, kadang-kadang didasari oleh emosi yang berfungsi sebagai semacam penyaluran frustrasi atau pengalihan bentuk mekanisme pertahanan ego. Prasangka seringkali merupakan bentuk sikap negatif yang didasari oleh kelainan kepribadian pada orang-orang yang frustrasi, namun biasanya bersifat sementara. 
Banyak para ahli mengasumsikan bahwa sikap seseorang berdampak pada prilaku yang muncul, sebab berdasarkan pada keyakinan terhadap sesuatu atau objek tersebut maka ia akan berprilaku cenderung condong pada sikap yang diyakininya. Penelitian yang dilakukan oleh Kelley \& Miler (1974 dalam O. Sear, 1998 : 150), menganalisis survei berskala besar yang diadakan selama empat kampanye pemilihan presiden Amerika dari tahun 1952 sampai 1964. Sikap partisipan pemberi suara seperti yang diungkapkan dalam wawancara sebelum pemilihan, mempunyai hubungan yang tinggi dengan prilaku voting yang sebenarnya yakni: 85 persen responden memperlihatkan kesesuaian antara sikap dan prilaku.

Selain itu pada penelitian yang lain (dalam O. Sear 1998: 150), dengan megambil sejumlah sampel yang terdiri dari wanita Taiwan yang sudah menikah ditanya "apakah anda menginginkan anak lagi?". Dalam tiga tahun berikutnya, 64 persen menjawab "ya" telah melahirkan, dan hanya 19 persen yang menjawab "tidak" masih mempunyai anak lagi. Schuman \& Jhonson (1976: 199 dalam O. Sear 1998: 150), menyimpulkan bahwa sebagian besar penelititan sikap - perilaku memberikan hasil yang positif. Korelasi yang terjadi cukup meluas untuk menunjukkan bahwa paksaan kausal yang penting turut dilibatkan, apapun proses kausal yang mendasari seseorang.

Namun ada juga para peneliti mengatakan bahwa sikap tidak selalu berdampak pada prilaku yang dimunculkan, hal ini tergantung pada seberapa kuat keyakinan yang dipegang. Seperti penelitian yang dilakukan oleh Wicker (1969 dalam O. Sear 1998: 149), dia melakukan penelitian dengan menguji konsistensi sikap dan prilaku dalam masalah hubungan ras, kepuasan kerja dan menyontek di kelas. Dengan meringkaskan 31 penelitian yang terpisah, Wicker menyimpulkan yaitu: "lebih besar kemungkinan bahwa sikap kurang atau hanya sedikit berhubungan dengan perilaku nyata ketimbang kemungkinan bahwa sikap mempunyai hubungan yang erat dengan tindakan".

Kesesuaian antara sikap dengan prilaku yang muncul tergantung pada apakah sikap itu merupakan sikap yang kuat dan jelas atau tidak sehingga konsisten, sebaliknya jika sikap itu lemah dan ambivalen maka akan memunculkan ketidak-konsistenan dengan prilaku yang muncul. Hal ini seperti yang diungkapkan oleh Kelley \& Miller (1974 dalam O. Sear, 1998:
150), menemukan bahwa sebagian besar ketidak-konsistenan sikap-voting muncul dari pemilih yang mulai dengan pilihan sikap yang lemah atau bertentangan. Demikian pula, perilaku yang konsisten tidak akan muncul bila komponen afeksi dan kognisi sikap bertentangan seperti diungkapkan oleh Norman. (1975 dalam O. Sear, 1998: 150).

Segala sesuatu yang mendukung sikap yang kuat pasti meningkatkan konsistensi sikap - prilaku, tentu saja salah satu faktornya adalah beberapa kali kita terdorong untuk berlatih dan mempraktekkan sikap kita. Fazio dkk (1982 dalam O. Sear, 1998: 150) memperlihatkan bahwa pada saat orang memikirkan dan mengekspresikan sikap mereka, prilaku mereka selalu lebih konsisten dengan sikapnya.

Pengalaman pribadi yang diperoleh yang langsung berkaitan dengan suatu persoalan membuat kita lebih banyak memikirkan dan membicarakannya daripada jika hal ini jauh dari kita, oleh sebab itu salah satu hipotesis yang diformulasikan adalah "bahwa kita akan memiliki sikap yang lebih kuat terhadap suatu objek sikap bila kita memiliki pengalaman langsung dengan objek itu, daripada bila kita hanya mendengar tentang objek itu dari orang lain, atau hanya membacanya. Bila kita memiliki sikap yang lebih kuat terhadap suatu hal, maka sikap itu juga akan konsisten terutama dengan prilaku yang relevan" (O. Sear, 1998: 150).

Relevansi sikap terhadap prilaku akan terjadi bila semakin besar relevansi spesifik sikap terhadap prilaku, semakin tinggi korelasi antara kedua hal tersebut. Sikap mempunyai sedikit perbedaan dalam tingkat relevansinya terhadap tindakan yang dibicarakan, pada umumnya prilaku cenderung lebih konsisten dengan sikap yang mempunyai relevansi spesifik dengan prilaku tersebut ketimbang dengan sikap yang sangat umum yang dapat diterapkan pada kelompok prilaku potensial yang jauh lebih besar.

\section{Kerja sama}

Kerjasama adalah kegiatan kerja beberapa orang untuk mencapai suatu tujuan, kriteria utama tingkah laku kerjasama ialah persepsi tentang tujuan bersama. Tujuan ini bernilai penting bagi tiap anggota kelompok dan tidak bisa dicapai dengan bekerja sendirian, disamping itu masih ada beberapa hal seperti 
motivasi bekerjasama, penghargaan terhadap kemampuan anggota lain dan kepercayaan bahwa kelebihan yang dimilki seeorang anggota tidak akan merugikan anggota lainnya. Dengan adanya dasar-dasar kerjasama tersebut, maka diantara anggota tumbuh keterbukaan, kesediaan saling memperhatikan dan mengisi kebutuhan.

Menurut Pareek, (1996: 187) kerjasama dapat didefinisikan sebagai kegiatan kerja beberapa orang untuk mencapai suatu tujuan yang dianggap dapat dibagi. Kriteria utama dari kerjasama adalah adanya persepsi yang sama dari anggota kelompok mengenai tujuan yang akan dicapai.

Sedangkan menurut Arnold dan Meiili (1975: 256, dalam Esyenck). Kerjasama adalah (1) suatu cara bertingkah laku, dimana aktivitas perorangan berkaitan atau tergantung pada aktivitas orang lainnya. (2) kesediaan untuk berpartisipasi, berbagai beban kerjasama dan semacamnya.

Dari batasan-batasan di atas dapat ditarik sebuah simpulan, bahwa kerjasama merupakan kegiatan saling mempengaruhi satu sama lain dan ada keterbukaan untuk saling membantu dengan tidak mendominasi atas anggota yang lain.

Mengingat bahwa kerjasama merupakan kegiatan dua orang atau lebih, tentunya ada beberapa hal yang menguatkan agar aktivitasnya bisa berjalan dengan efektif. Selain dari adanya tujuan bersama, juga ada beberapa hal yang mendasari kerjasama sebagaimana yang diungkapkan Pareek (1996, 197 - 202) yaitu:

Motivasi kerjasama. Pada dasarnya ada kebutuhan pokok manusia untuk selalu berhubungan dengan orang lain, motif bergaul inilah yang merupakan dasar kerjasama. Motivasi ini tercermin dari perhatian seseorang pada orang lain dan kesediaannya untuk menunda pemuasan kebutuhan sendiri demi kepentingan orang lain atau kelompok.

Norma-norma. kelompok dapat meningkatkan atau mengurangi motif ini, apabila dengan kerjasama orang merasa mendapat keuntungan maka ia akan mengulangi tindakan tersebut. Dan sebaliknya bila ia mendapat keuntungan lebih besar dengan bersaing, maka ia tidak akan mau untuk bekerjasama.

Persepsi tentang tujuan bersama. Kriteria utama prilaku kerjasama adalah adanya persepsi tentang tujuan bersama yang tidak bisa dicapai bila mereka bekerja sendiri, tujuan ini disebut juga dengan tujuan super-ordinat. Beberapa faktor membantu berkembangnya suatu tujuan super-ordinat, pertama tujuannya harus menarik dan diinginkan oleh sebagian besar anggota. Yang kedua yaitu tujuan harus dianggap dapat dicapai bersama.

Persepsi tentang kekuasaan. Setiap anggota dalam kelompok memiliki semacam kekuasaan untuk mengimbali dan menghukum. Hukuman dapat dilakukan dengan jalan menghalangi orang untuk mendapatkan hasil yang diinginkannya. Misalnya, memperlambat sesuatu, menyembunyikan informasi atau memberikan informasi yang salah. Dengan adanya persepsi bahwa anggota lain memiliki kekuasaan atau kemampuan dalam pencapaian tujuan, maka individu cenderung mau bekerjasama dengan anggota lain.

Saling percaya. Adanya persepsi tentang kekuasaan harus disertai adanya kepercayaan bahwa kekuasaan yang dimiliki anggota lain tersebut tidak akan digunakannya untuk merugikan dirinya.

Keadaan yang memaksa. Seringkali orang menaruh prasangka dan tidak bisa bekerjasama dengan orang lain, melalui pengalaman kebersamaan dapat dikembangkan norma-norma bersama. Secara perlahan penilaianpenilaian subyektif dilepaskan dan dikembangkan pandangan baru, hal ini membantu timbulnya kerjasama.

\section{Kepuasan kerja}

Pada dasarnya setiap karyawan ingin mendapatkan kepuasan didalam bekerja, oleh karenanya banyak faktor yang dapat mempengaruhi untuk mendapatkannya. Namun sebelum melihat faktor-faktor apa saja yng mempengaruhi hal tersebut, perlu kiranya kita ketahui terlebih dahulu mengenai pengertian kepuasan kerja. Berikut adalah merupakan beberapa pendapat tentang pengertian kepuasan kerja dari para ahli, yakni :

Kepuasan kerja menurut Howell \& Dipboye (dalam Munandar, 2001: 350) yaitu, Kepuasan kerja sebagai hasil keseluruhan dari derajat rasa suka atau tidak sukanya tenaga kerja terhadap berbagai aspek dari pekerjaannya. Dengan kata lain kepuasan kerja mencerminkan sikap tenaga kerja terhadap pekerjaannya. Menurut Wexley \& Yuki (1977: 77) kepuasan kerja adalah perasaan-perasaan pekerjaannya yang merupakan sikap terhadap 
pekerjaan yang didasarkan pada evaluasi terhadap aspek-aspek yang berbeda tentang pekerjaan. Sikap ini mengambarkan pengalamanpengalaman menyenangkan atau tidak menyenangkan dalam pekerjaan dan harapan-harapan mengenai pengalaman-pengalaman mendatang.

Menurut Beck (1995; 206), kepuasan kerja adalah perasaan menyenangkan yang dihasilkan dari persepsi bahwa satu pekerjaan dapat memenuhi atau menghasilkan salah satu nilai penting dari pekerjaan itu sendiri. Menurut Osborn $(1982 ; 140)$ kepuasan kerja adalah derajat positif atau negatif perasaan seseorang mengenai tugas-tugas pekerjaannya, tatanan kerja serta hubungan antar sesama pekerja.

Menurut Luthan (1995; 126), kepuasan kerja adalah aktivitas membandingkan antara hasil dengan harapan dan kepuasan kerja berhubungan dengan sikap. Menurut Tiffin (1958, dalam As'ad, 19-87: 105) berpendapat bahwa kepuasan kerja berhubungan erat dengan sikap dari karyawan terhadap pekerjaannya sendiri, situasi kerja, kerjasama antara pimpinan dengan sesama karyawan.

Menurut As'ad (1987: 105) berdasarkan beberapa pendapat dari tokoh, beliau memberi batasan bahwa kepuasan kerja adalah perasaan seseorang terhadap pekerjaan. Menurut Robbins (2001: 139), kepuasan kerja (job satisfaction) merujuk pada sikap umum seorang individu terhadap pekerjaannya. Seseorang dengan tingkat kepuasan kerja tinggi menunjukkan sikap yang positif terhadap kerja itu, seseorang yang tak puas dengan pekerjaan menunjukkan sikap yang negative.

Dari beberapa batasan definsi diatas dapat diambil simpulan bahwa kepuasan kerja merupakan sikap atau perasaan pekerja terhadap pekerjaannya, baik yang menyenangkan atau tidak meyenangkan. Kepuasan kerja menunjukkan sikap yang berdasarkan pada persepsi atau penilaian kerja seorang pekerja terhadap berbagai aspek dari tugas-tugas, situasi kerja, serta hubungan antar pekerja. Dampak dari kepuasan kerja sangat berpengaruh pada kelangsungan hidup dari organisasi, bilamana hal ini terjadi maka produktivitas yang dihasilkan mungkin akan turun dan bisa menghambat dari tujuan organisasi.

Adapun hipotesis dalam penelitian ini adalah "Terdapat hubungan antara sikap terhadap kerjasama kelompok dengan kepuasan kerja pada karyawan PT. Pindad Persero (Departemen. Tempa \& Cor).

\section{METODE PENELITIAN}

Desain yang akan digunakan dalam penelitian ini adalah rancangan non eksperimental dengan metode korelasioanal, dengan maksud yaitu untuk mengetahui ada tidaknya hubungan antara dua atau beberapa variabel (Arikunto, 2000: 326). Dalam hal ini untuk melihat hubungan antara variabel sikap dan kepuasan kerja. Pada penelitian ini juga digunakan metode statistik untuk menganalisis data yang berguna untuk pengujian hipotesa yang diajukan peneliti.

Subjek penelitian adalah benda, hal atau orang tempat data untuk variabel penelitian melekat, dan yang dipermasalahkan (Arikunto, 2000 : 125). Pada penelitian ini subjek yang akan diambil adalah para karyawan PT. Pindad Persero. Adapun dalam penelitian ini yang dijadikan sebagai populasinya adalah para karyawan PT Pindad persero (departemen. tempa dan cor) Bandung yang berjumlah 205 orang yang kemudian akan diambil sampel sebanyak $25 \%$, jadi total sampel sebanyak 52 orang. Karena jumlah populasi lebih dari 150 orang, maka sampel bisa diambil sebanyak $25 \%$ (Arikunto, 2000 : 125).

Untuk mengukur sikap karyawan terhadap kerjasama kelompok, maka digunakan skala sikap yang dibuat dengan bentuk skala likert. Skala ini berisikan 40 pertanyaan / pernyataan yang mengukur aspek afektif, kognitif dan konatif.

Untuk mengukur kepuasan kerja menggunakan skala yang diadaptasi dari NSQ (Need Statisfaction Questionere) dari Porter (1961), dalam skala ini terdapat 54 pertanyaan yang mengukur karakteristik pekerja, situasi pekerjaan dan kraktristik pekerja. Pada setiap item diberikan 2 alternatif jawaban yaitu (a) untuk keadaan yang dialami sekarang dan (b) untuk keadaan yang seharusnya ada.

Penelitian ini bertujuan untuk melihat hubungan antara sikap terhadap kerjasama kelompok dengan kepuasan kerja pada karyawan PT Pindad persero (departemen tempa \& cor) Bandung. Oleh karena itu diperlukan analisis dari pengumpulan data yang diperoleh nanti. Dalam penelitian ini menggunakan Statistik uji koefisiensi korelasi dari Rank Spearman (Siegel. 1992), dengan alasan bahwa data dalam penelitian ini berpasangan, data berskala ordinal dan teknik statistik berbentuk nonparametrik. 


\section{HASIL DAN PEMBAHASAN}

Berdasarkan hasil analisis data, diketahui bahwa antara sikap terhadap kerjasama kelompok dengan kepuasan kerja pada karyawan PT. Pindad Persero Bandung (Departemen Tempa \& Cor) kurang signifikan. Hal ini ditunjukkan oleh $t_{\text {hitung }}$ yang memiliki nilai lebih kecil dari $t_{\text {tabel }}$ (untuk uji satu sisi).

Dari hasil perhitungan deskriptif dinyatakan bahwa tingkat sikap terhadap kerjasama kelompok dengan kepuasan kerja berada pada level sedang, yang mana ada sekitar 24 orang (47\%) yang sikapnya berada pada level sedang, dan karyawan menyatakan tingkat kepuasannya berada pada level sedang sebanyak 30 orang (59\%) (dapat dilihat pada tabel 4.4). Artinya bahwa pada dasarnya sikap terhadap kerjasama kelompok mempunyai korelasi dengan kepuasan kerja.

Menurut Robbins (2001: 149 - 150), ada beberapa hal yang menentukan kepuasan kerja yaitu kerja yang secara mental menantang, ganjaran/upah dan kebijakan promosi yang adil, kondisi lungkungan kerja yang mendukung, rekan kerja sejawat yang saling mendukung dan kesesuian natra tipe kperibadian dengan kepuasan kerja.

Berdasarkan hasil penelitian pada karyawan PT. Pidad Persero (dept. Tempa \& Cor), bahwasannya sikap yang positif dari rekan kerja terhadap kerjasama kelompok memiliki tingkat signifikasi yang relatif rendah pada kepuasan kerja. Hal ini diperoleh dari hasil analisis statistik, dari kedua variabel tersebut. Dalam penelitian ini terdapat korelasi namun kurang signifikan, hal ini dapat dilihat pada hasil perhitungan. Korelasi yang diharapkan adalah korelasi negatif, artinya bahwa semakin tinggi sikap terhadap kerjasama, maka semakin tinggi tingkat kepuasan kerja pada karyawan.

Kedua variabel tersebut kemudian dikorelasikan masing-masing aspeknya untuk melihat aspek yang paling dominan berpengaruh pada kepuasan kerja para karyawan PT. Pindad Persero (dept. Tempa \& Cor). Berdasarkan perhitungan, diperoleh data bahwa aspek hubungan antar rekan kerja dengan karakteristik pekerjaan tingkat koefisiennya lebih tinggi dibandingkan dengan aspek yang lainnya.

Sikap terhadap kerjasama kelompok adalah merupakan predisposisi yang ada pada individu untuk memberikan respon baik positif atau negatif terhadap lingkungannya yang me- libatkan aspek afektif, kognitif dan konatif yang tujuannya ialah agar individu dapat menyelesaikan tugas yang diberikan untuk dikerjakan secara kelompok.

Didalam bekerja secara berkelompok tentunya dituntut peran kerjasama antar anggota untuk mendukung menyelesaikan pekerjaan, sikap positif yang diberikan atau ditunjukkan oleh anggota kelompok akan sangat membantu proses kerjasama yang tentunya selain tugas akan terselesaikan dengan lebih baik, juga akan membuat suasana dalam kelompok akan lebih kondusif.

Dengan adanya kerjasama yang baik akan memberikan kontribusi yang lebih pada setiap anggota kelompok yang lain, hal ini terjadi karena sesama anggota saling mengisi kekurangan yang ada pada individu.

\section{SIMPULAN DAN SARAN}

\section{Simpulan}

Berdasarkan hasil analisis dan pembahasan tentang hubungan antara sikap terhadap kerjasama kelompok dengan kepuasan kerja pada karyawan PT. Pindad Persero Bandung (dept. Tempa \& Cor), dapat ditarik simpulan sebagai berikut:

Hubungan antara sikap terhadap kerjasama kelompok dengan kepuasan kerja pada karyawan PT. Pindad Persero Bandung (dept. Tempa \& Cor) kurang signifikan, yang mengacu pada standar Guilford. Semakin tinggi skor skala sikap, maka semakin rendah skor skala kepuasan kerja, hal ini berarti semakin tinggi skap terhadap kerjasama kelompok. Maka tingkat kepuasan pada kerja karyawan juga akan tinggi, begitu pula sebaliknya.

Pada karyawan P.T Pindad Persero (dept. Tempa \& Cor), bahwasannya aspek kemampuan dalam menyelesaikan tugas dengan aspek karakteristik pekerjaan cenderung lebih memberikan potensi kepada karyawan untuk memperoleh kepuasan kerja dibandingkan dengan aspek yang lainnya.

\section{Saran}

Berdasarkan hasil penelitian yang telah dilakukan, ada beberapa saran agar sekiranya dapat dijadikan sebagai bahan pertimbangan bagi pihak-pihak yang memerlukannya, yaitu sebagai berikut: 
Berdasarkan hasil penelitian ini, diperoleh data bahwasannya untuk jenis atau tipe pekerjaan yang sifatnya harus dikerjakan secara berkelompok, tipe kepribadian dan jenis pekerjaan cenderung dominan bagi karyawan untuk memperoleh kepuasan kerja.

Untuk menunjang berbagai kamampuan dalam menyelesaikan pekerjaan agar memperoleh kepuasan kerja, agar sekiranya para karyawan lebih mengenal dan meningkatkan kualitas kepribadian dan lebih menyesuaikan antara kemampaun diri dengan karakteristik pekerjaan yang ada.

Bagi penelitian selanjutnya, agar lebih dipertimbangkan lagi mengenai perlunya untuk menjaring data-data kualitatif lebih banyak lagi sebagai bahan untuk menunjang dan melengkapi hasil data kuantitatif, sehingga dapat menghasilkan analis yang lebih akurat lagi.

\section{DAFTAR PUSTAKA}

Arikunto, Suharsimi. Prof. Dr. 2000 Manajemen Penelitian. Rineka Cipta. Jakarta.

Azwar, Saefuddin. Drs. M.A. 2004. Penyusunan Skala Psikologi. Pustaka Pelajar Offset. Yogyakarta.

Azwar, Saefuddin. Drs. M.A. 2003. Sikap Manusia Teori dan Pengukurannya, Pustaka Pelajar Offset. Yogyakarta

Beck. Hollen .1995. Managemen of Organizationl Behavior., Second Edition. New Jwrsey : by Prentice-hall, Inc A Simon \& Schuster Company Englewood Cliffs.

David J Schwartz, Ph. D 2006-06-19. Berfikir dan Berjiwa Besar, PT. Pustaka Delapratasa.

Eysenc, H.J. dkk. 1975. Encyclopedia of Psychology. Fontana, Great Britain.

Friedenberg, Lisa. 1995. Psychological Testing Design, Analysis, and Use. Allyn \& Bacon. Massachusetts.

Kessen, Stan. 1986. Aspek Manusia Dalam Organisasi.(edisi terjemah). Erlangga. Jakarta.

Luthan,Fred. 1996. Organizational Behavior, Fourh Editio.Mc. New Delhi : Graw Hill Book Company.

Miner, B. John. 1992. Industrial Organization Psychology. Mc.Graw-Hill. Singapura.

Milton, Charles R.. 1981. Human Behavior in Organizations. Three Levels Of Behavior. Pretice-Hall, inc. New Jersey.
Munandar, A.S., 2001. Psikologi Industri dan Organisasi, Jakarta: Universitas Indonesia Press.

Moh. As'ad. 1982 Psikologi Industri.(edisi revisi) Liberty. Yogyakarta.

Nazir, Moh. Ph.D. 1985. Metode Penelitian Ghalia Indonesia. Jakarta.

Newcomb \& dkk, 1985. Psikologi Sosial. Edisi Indonesia. CV. Diponegoro. Bandung.

Nigel C. Benson dan Simon Grove, 2002. Psikologi for Beginners, Mizan, Bandung.

Onong Uchjana Effendi. Drs M.A 1983. Psikologi Manajemen, Alumni. Bandung.

Osborn. 1982. Managing Organizational Behavior, Five Edition. New York: John Willey \& Sons, Inc.

Pareek, Uday. Dr. 1996. Prilaku Organisasi, Seri Manajemen No. 98. PT. Pustaka Binaman Pressindo dan Lembaga pendidikan dan Pembinaan Manajemen (LPPM). Jakarta.

Riduwan. Drs. M.B.A 2005. Skala Pengukuran Variabel-variabel Penelitian. Alfabeta. Bandung.

Robbins P. Stephen, 2001 Prilaku Organisasi. Konsep, Kontrovesi, aplikasi. Versi Bahasa Indonesia. Pearson Education Asia Pte. Ltd Dan PT. Prenhallindo. Jakarta.

Said. M. 198. 101 Hadist Tentang Budi Luhur. PT. Al-Ma'arif. Bandung.

Sarwono. S.W. 2001. Psikologi Sosial. PT. Balai Pustaka. Jakarta..

Schernerhorn, Jr. John,dkk. 1982. Managing Organizational Behavior. John Wiley \& Sons. New york.

Sears, O. David., Freedman, L. Jonathan., Peplau, L. Anne. 1994. Social Antropology Fifth Edition (edisi terjemah: Psikologi Sosial). PT Gelora Aksara Pratama.

Shaw, Marvin. E. 1970. Group Dynamics, second edition. Tata-Mc.Graw-Hill. Inc. Newyork.

Siegel, Sidney. Prof. 1994. Nonparametric Statistics for the Behavioral Science (edisi terjemah). PT Gramedia. Jakarta.

Soenarjo, Prof.. S.H. 1971, Al-Qur'an dan Terjemahnya. Jakarta.

Sudjana. Prof. DR., M.A., M.Sc. 1996. Metoda Statistika edisi keenam. Tarsito: Bandung.

Sutrisno, Hadi. Prof. Drs . MA . 2001. Metodologi Research. Andi .Yogyakarta. 
Syah, Muhibbin, Med. 2005. Psikologi Pendidikan (dengan pendekatan baru). PT. Remaja Rosdakarya. Bandung.

W.A Gerungan. DR.DIPL. PSYCH. 2002. Psikologi Sosial. Reflika Aditama. Bandung.

Wexley \& Yuki. 1977. Organizational Behavior and Personal Psychology. First
Printing. USA : Richard D. Irein Inc. Homewood. Illionist.

Widiyanta, Ari. 2007. Sikap Terhadap Lingkungan Alam (Tinjauan Islam dalam Menyelesaikan Masalah Lingkungan). Penelitian. Universitas Sumatera Utara. Yusuf R \& Asyarie Sukmadjaja, 2003. Indeks Al-qur'an, Pustaka, Bandung. 